Microprocessors and Microcomputers 
Macmillan Basis Books in Electronics

Series Editor Noel M. Morris

Beginning BASIC P. E. Gosling

Continuing BASIC P. E. Gosling

Digital Electronic Circuits and Systems Noel M. Morris

Electrical Circuits and Systems Noel M. Morris

Linear Electronic Circuits and Systems G. D. Bishop

Microprocessors and Microcomputers Eric Huggins

Semiconductor Devices Noel M. Morris 


\section{Microprocessors and \\ Microcomputers}

their use and programming

Eric Huggins, M.A., C.Eng.,

F.I.Prod.E., M.I.E.E., M.I.M.C. 
๑) Eric Huggins 1979

All rights reserved. No part of this publication may be reproduced or transmitted, in any form or by any means, without permission.

First edition 1979

Reprinted 1980,1981

Published 1979 by

THE MACMILLAN PRESS LTD

London and Basingstoke

Associated companies in Delhi Dublin

Hong Kong Johannesburg Lagos Melbourne

New York Singapore and Tokyo

Typeset in IBM Press Roman by

Reproduction Drawings Ltd, Sutton, Surrey

\section{British Library Cataloguing in Publication Data}

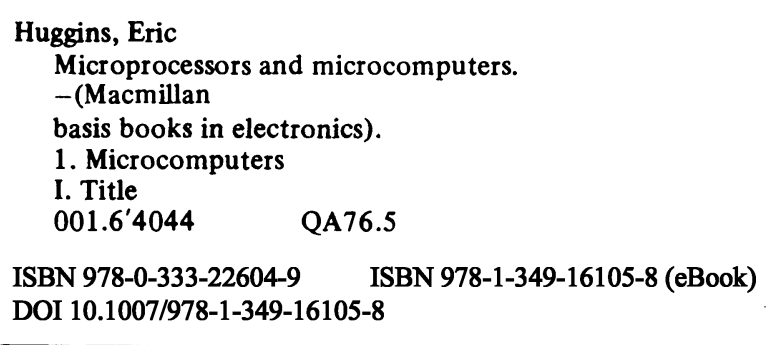

The paperback edition of this book is sold subject to the condition that it shall not, by way of trade or otherwise, be lent, resold, hired out, or otherwise circulated without the publisher's prior consent in any form of binding or cover other than that in which it is published and without a similar condition including this condition being imposed on the subsequent purchaser. 


\section{Contents}

Foreword $\quad$ ix

Preface $\quad$ xi

1. The Microprocessor Revolution 1

1.1 Historical 1

1.2 The Transistor 2

$\begin{array}{lll}1.3 & \text { The Microprocessor } & 4\end{array}$

1.4 The Future 5

2. How a Computer Works 6

$\begin{array}{lll}2.1 & \text { An Allegorical Computer } & 6\end{array}$

2.2 A Typical Problem 9

3. The Binary System 16

$\begin{array}{ll}3.1 \text { Radices } & 16 \\ 3.2 & 16\end{array}$

$\begin{array}{ll}3.2 \text { The Binary System } & 16\end{array}$

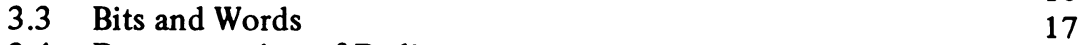

$\begin{array}{lll}3.4 & \text { Representation of Radices } & 18\end{array}$

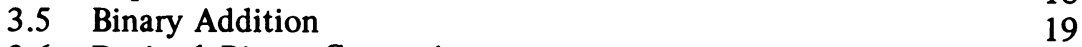

$\begin{array}{ll}3.6 \text { Decimal-Binary Conversion } & 19\end{array}$

3.7 Binary-Decimal Conversion 20

$\begin{array}{ll}3.8 & \text { Negative Numbers } \\ 3.9 & 23\end{array}$

$\begin{array}{ll}3.9 \text { Binary Subtraction } & 23\end{array}$

$\begin{array}{ll}3.10 \text { Two's complement } & 25\end{array}$

$\begin{array}{ll}3.11 \text { Overflow } & 25\end{array}$

4. Representation 28

$\begin{array}{lll}4.1 & \text { Quartal } & 28 \\ 4.2 & & 28\end{array}$

$\begin{array}{lll}4.2 \text { Octal } & 29\end{array}$

$\begin{array}{lll}4.3 \text { Hexadecimal } & 30\end{array}$

4.4 Internal Representation 31

$\begin{array}{lll}4.5 & \text { Strings } & 32\end{array}$

4.6 Alphabetic and Other Characters 32

4.7 Binary Coded Decimal $\quad 35$

4.8 Representation of Instructions $\quad 35$ 
5. Elements of Programming 38

$\begin{array}{lll}5.1 & \text { Sizes of Numbers } & 38\end{array}$

5.2 Branches, Jumps and Loops $\quad 43$

5.3 Revised Format $\quad 44$

$\begin{array}{lll}5.4 & \text { Conditional Transfers } & 46\end{array}$

$\begin{array}{lll}5.5 & \text { Input/Output } & 48\end{array}$

5.6 Action on Overflow $\quad 50$

6. Memory Stores $\quad 52$

6.1 Back-up Stores $\quad 52$

6.2 Immediate Access Memory $\quad 52$

6.3 Volatility of Memories $\quad 54$

6.4 Hardware, Software and Firmware $\quad 54$

6.5 Some Memory Definitions $\quad 55$

7. Peripheral Equipment and Devices 56

$7.1 \quad$ Input Devices (Literal) $\quad 56$

$\begin{array}{ll}7.2 \text { Input Devices (Physical) } & 61\end{array}$

7.3 Output Devices (Literal) 63

7.4 Output Devices (Physical) 65

$\begin{array}{lll}7.5 & \text { Input/Output Devices } & 68\end{array}$

7.6 Serial-Parallel Transfer of Information 71

8. Applications for Microprocessors $\quad 72$

$\begin{array}{lll}\text { 8.1 General-purpose Microcomputers } & 72\end{array}$

$\begin{array}{lll}8.2 & \text { On-line Computing } & 73\end{array}$

9. Microprocessor Hardware 76

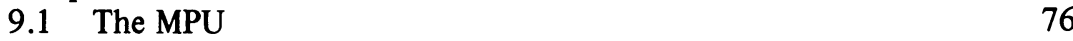

$\begin{array}{lll}9.2 & \text { MPU Internal Units } & 77\end{array}$

$\begin{array}{lll}9.3 & \text { Bus Lines } & 79\end{array}$

$\begin{array}{lll}9.4 & \text { Memories } & 81\end{array}$

$\begin{array}{ll}9.5 & \text { Input/Output }\end{array}$

10. Software $\quad 85$

$\begin{array}{ll}10.1 \text { Levels of Language } & 85\end{array}$

$\begin{array}{ll}10.2 \text { Commercial Software } & 87\end{array}$

$\begin{array}{lr}\text { 11. The Stack } & 89\end{array}$

$\begin{array}{ll}11.1 \text { Subroutines } & 89\end{array}$

11.2 The Stack as a Jotter or Scratch Pad 92

$\begin{array}{ll}11.3 \text { Interrupts } & 93\end{array}$

11.4 Alternatives to the LIFO Stack 93

12. Boolean Notation 94

12.1 Truth Tables $\quad 94$

12.2 Gates and Logic Elements 96 
13. Addressing Modes 102

13.1 Inherent Addressing 102

$\begin{array}{ll}13.2 \text { Direct Addressing } & 102\end{array}$

$\begin{array}{ll}13.3 \text { Immediate Addressing } & 103\end{array}$

$\begin{array}{ll}13.4 \text { Base Page Addressing } & 106\end{array}$

$\begin{array}{ll}\text { 13.5 Program Counter Relative Addressing } & 107\end{array}$

$\begin{array}{ll}\text { 13.6 Datum Relative Addressing } & 107\end{array}$

$\begin{array}{ll}13.7 \text { Datum Addressing } & 110\end{array}$

$\begin{array}{ll}13.8 \text { Indirect Addressing } & 110\end{array}$

13.9 Datum Indirect Addressing $\quad 111$

14. Integer Multiplication and Division Subroutines 112

$\begin{array}{ll}14.1 \text { Binary Multiplication } & 112\end{array}$

$\begin{array}{ll}14.2 \text { Procedures } & 116\end{array}$

$\begin{array}{ll}14.3 \text { Binary Division } & 117\end{array}$

14.4 Rounding $\quad 119$

15. Floating Point Arithmetic $\quad 126$

$\begin{array}{ll}15.1 \text { Magnitude and Precision } & 126\end{array}$

$\begin{array}{ll}15.2 \text { Exponent and Mantissa } & 127\end{array}$

15.3 Representation of Floating Point Numbers $\quad 127$

15.4 Floating Point Addition and Subtraction 130

15.5 Normalising 132

16. Program for Floating Point Addition and Subtraction 134

$\begin{array}{ll}\text { 17. Floating Point Multiplication and Division } & 150\end{array}$

$\begin{array}{ll}17.1 \text { Floating Point Multiplication } & 150\end{array}$

$\begin{array}{ll}17.2 \text { Floating Point Division } & 157\end{array}$

18. Other Functions 159

18.1 Square Roots and Other Powers 159

$\begin{array}{ll}18.2 \text { Logarithms } & 160\end{array}$

$\begin{array}{ll}18.3 \text { Antilogarithms } & 163\end{array}$

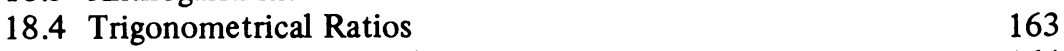

18.5 Inverse Trigonometrical Ratios 164

$\begin{array}{ll}18.6 \text { Random Numbers } & 164\end{array}$

$\begin{array}{lll}18.7 & \text { Look-up Tables } & 168\end{array}$

18.8 Binary Coded Decimal (BCD) Arithmetic 168

19. Input/Output 172

$\begin{array}{lll}19.1 \text { Interface Devices } & 173\end{array}$

$\begin{array}{ll}19.2 \text { Interrupt Routines } & 181\end{array}$

19.3 Direct Memory Access 182

20. Loading and Running a Program 184

$\begin{array}{ll}20.1 \text { Assembly } & 184\end{array}$

$\begin{array}{ll}20.2 \text { Loading the Program } & 189\end{array}$ 
$\begin{array}{ll}20.3 \text { Bootstrapping } & 200\end{array}$

20.4 Dedicated Microprocessors 201

21. Selecting a Microprocessor

202

21.1 The Needs of the OEM

202

21.2 The Needs of Other Users

203

$\begin{array}{lr}\text { 22. Conclusion } & 205\end{array}$

$\begin{array}{lr}\text { Appendix I: Powers of } 2 & 207\end{array}$

Appendix II: Binary-Hexadecimal-Decimal Ready Reckoner 208

$\begin{array}{lr}\text { Appendix III: ASCII Full Set } & 209\end{array}$

$\begin{array}{lr}\text { Appendix IV: SIMNIC Instructions } & 213\end{array}$

$\begin{array}{lr}\text { References } & 218\end{array}$

$\begin{array}{lr}\text { Index } & 219\end{array}$ 


\section{Foreword}

Technological progress has nowhere been more rapid than in the fields of electronics, electrical, and control engineering. The Macmillan Basis Books in Electronics Series of books have been written by authors who are specialists in these fields, and whose work enables them to bring technological developments sharply into focus.

Each book in the series deals with a single subject so that undergraduates, technicians and mechanics alike will find information within the scope of their courses. The books have been carefully written and edited to allow each to be used for self-study; this feature makes them particularly attractive not only to readers approaching the subject for the first time, but also to mature readers wishing to update and revise their knowledge.

Noel M. Morris 


\section{Preface}

In no other industry in the history of mankind have prices fallen as rapidly as they have in the computer industry. Use of the first digital electronic computers was limited to a few universities and to large commercial and government establishments. A quarter of a century later they are being used (in the form of microprocessors and microcomputers) by schools and colleges for classroom use, by engineers for incorporation into products ranging from nuclear power plants to washing machines, by even the smallest businesses for accountancy and automatic typing and by home-construction enthusiasts for an ever increasing variety of applications. The limit to the market is no longer the price but the ability of the user to understand the operation and programming of the equipment.

No longer is a working knowledge of the high level languages, ALGOL, FORTRAN, COBOL, BASIC etc., sufficient. To get value from a microprocessor the user has to know how a computer works and to understand binary arithmetic and programming at machine level. He has, for example, to know what to do with the carry bit and to appreciate the implications of two's complement overflow. This book aims to meet these needs.

My introduction to this problem arose in two ways. As an engineer I have been using computers occasionally, as my work has required, for nearly 20 years. It is part of my job to keep up-to-date with the state of the art and microprocessors will play an increasingly important role in this.

Quite separately I saw potential for building a small microprocessing system at home to use for statistical purposes and to amuse my grandchilden by playing noughts and crosses and more sophisticated computer games. (It must be admitted that Grandpa was not without hopes of amusing himself with the project!) Before buying the hardware, I realised that I must investigate the programming aspects. I therefore sent for the programming manual of the microprocessing unit (MPU) I intended to use. It did not give me the information I was seeking. The authors assumed a level of understanding that I, for one, did not possess-and I am not exactly a greenhorn. At different times I have written programs in half-a-dozen different programming languages and successfully run them on computers or numerically controlled machine tools, but this stuff was beyond me. I looked in vain for a textbook that would tell me in simple English what, for example, the FORTRAN statement

$$
\mathrm{I}=\mathrm{J} *(\mathrm{~K}+\mathrm{L})
$$


would look like in machine code. In desperation I sent for literature and manuals from other MPU manufacturers. I also found in the attic two 20-year-old books (now probably out of print) on programming the early computers.

Slowly I pieced all the information together and I made notes as I did so. In the belief that there may be other potential users of microprocessors who find themselves in the same position as I was in, I have assembled these notes, added a little I already knew--and this book is the result. I offer it to fellow engineers, students and home-construction enthusiasts in the hope that it will help them to enjoy the exciting opportunities microprocessors now offer.

The book is dedicated to Dorothy, whose patience, understanding and encouragement have particularly helped me during its writing. I know she will never be able, nor will she ever wish, to write a program or even to use a pocket calculator. She will continue, very happily, doing decimal arithmetic on her pretty fingers!

My thanks also to Miriam who, over the years, has always succeeded in transforming my appalling and deteriorating handwriting into exemplary typescript and to the Director of the Urwick Management Centre, Slough, on whose computer terminal the programs in this book were prepared. 